\title{
Genomic Resources for Sea Lice: Analysis of ESTs and Mitochondrial Genomes
}

\author{
Motoshige Yasuike • Jong Leong • Stuart G. Jantzen • \\ Kristian R. von Schalburg • Frank Nilsen • \\ Simon R. M. Jones • Ben F. Koop
}

Received: 9 March 2011 / Accepted: 22 June 2011 /Published online: 12 July 2011

(C) The Author(s) 2011. This article is published with open access at Springerlink.com

\begin{abstract}
Sea lice are common parasites of both farmed and wild salmon. Salmon farming constitutes an important economic market in North America, South America, and Northern Europe. Infections with sea lice can result in significant production losses. A compilation of genomic information on different genera of sea lice is an important resource for understanding their biology as well as for the study of population genetics and control strategies. We report on over 150,000 expressed sequence tags (ESTs) from five different species (Pacific Lepeophtheirus salmonis $(49,672$ new ESTs in addition to 14,994 previously reported ESTs), Atlantic L. salmonis (57,349 ESTs), Caligus clemensi $(14,821$ ESTs), Caligus rogercresseyi (32,135 ESTs), and Lernaeocera branchialis $(16,441$
\end{abstract}

Electronic supplementary material The online version of this article (doi:10.1007/s10126-011-9398-z) contains supplementary material, which is available to authorized users.

M. Yasuike $\cdot$ J. Leong $\cdot$ S. G. Jantzen $\cdot$ K. R. von Schalburg $\cdot$

B. F. Koop $(\square)$

Department of Biology, University of Victoria,

PO Box 3020 STN CSC, Victoria, BC V8W 3N5, Canada

e-mail: bkoop@uvic.ca

F. Nilsen

Department of Biology, University of Bergen,

5020 Bergen, Norway

S. R. M. Jones

Pacific Biological Station, Fisheries and Oceans Canada,

3190 Hammond Bay Road,

Nanaimo, BC V9T 6N7, Canada

Present Address:

M. Yasuike

Aquatic Genomics Research Center, National Research Institute of

Fisheries Science, Fisheries Research Agency,

2-12-4 Fukuura, Kanazawa,

Yokohama, Kanagawa 236-8648, Japan
ESTs)). For each species, ESTs were assembled into complete or partial genes and annotated by comparisons to known proteins in public databases. In addition, whole mitochondrial (mt) genome sequences of C. clemensi $(13,440 \mathrm{bp})$ and $C$. rogercresseyi $(13,468 \mathrm{bp})$ were determined and compared to L. salmonis. Both nuclear and mtDNA genes show very high levels of sequence divergence between these ectoparastic copepods suggesting that the different species of sea lice have been in existence for 37-113 million years and that parasitic association with salmonids is also quite ancient. Our ESTs and mtDNA data provide a novel resource for the study of sea louse biology, population genetics, and control strategies. This genomic information provides the material basis for the development of a $38 \mathrm{~K}$ sea louse microarray that can be used in conjunction with our existing $44 \mathrm{~K}$ salmon microarray to study host-parasite interactions at the molecular level. This report represents the largest genomic resource for any copepod species to date.

Keywords Lepeophtheirus salmonis · Caligus clemensi - $C$. rogercresseyi $\cdot$ Lernaeocera branchialis . Expressed sequence tags (ESTs) $\cdot$ Mitochondrial genome

\section{Introduction}

Copepods (Copepoda) are a group of small crustaceans found in various aquatic environments and they are described as the most abundant metazoans on earth (Humes 1994). The subclass Copepoda consists of over 250 described families, 2,600 genera, and 21,000 described species classified into ten orders (Walter and Boxshall 2008). Their life histories are diverse; planktonic and benthic copepods are an important ecological link in the 
aquatic food chain (Gee 1987; Ohman and Hirche 2001), but approximately one third of marine copepod species live as associates, commensals, or parasites on invertebrates and fishes (Humes 1994).

Parasitic copepods are commonly found both on farmed and wild marine finfish (Johnson and Fast 2004). They feed on host mucus, epidermal cells, tissues, and blood, the result of which causes physiological stress, immune dysfunction, impairment of swimming ability, and possibly death (Boxaspen 2006; Costello 2006; Johnson and Fast 2004; Tully and Nolan 2002). Members of the family Caligidae, especially the genera Caligus and Lepeophtheirus, are commonly referred to as sea lice (Costello 2006; Johnson et al. 2004; Pike and Wadsworth 1999). They are the most economically important parasites of the world salmon farming industry and may cause direct and indirect economic losses in the industry of $€ 300$ million (US $\$ 480$ million) annually (Costello 2009). In addition, there is concern that salmon farms elevate the risk of sea lice infections on wild salmon beyond that which naturally occurs and lead to a depression in the abundance of wild salmon stocks (Costello 2006; Heuch et al. 2005; Krkošek et al. 2007a; Krkošek et al. 2007b; Todd et al. 2006).

In the North Atlantic Ocean, Lepeophtheirus salmonis and Caligus elongatus account for the most serious infestations of cultured and wild salmonids (Johnson et al. 2004; Pike and Wadsworth 1999). In the eastern north Pacific Ocean, $L$. salmonis and Caligus clemensi have been found on farmed Atlantic salmon (Salmo salar) and wild Pacific salmon (Oncorhynchus spp.; Beamish et al. 2009; Beamish et al. 2005; Saksida et al. 2007). While L. salmonis is prevalent in both Atlantic and Pacific coasts, earlier studies suggested that the Pacific and Atlantic populations of L. salmonis are genetically distinct (Tjensvoll et al. 2006; Todd et al. 2004). More recent genomic studies strongly suggest that distinct species of L. salmonis exist in the Pacific and Atlantic Oceans following a separation that occurred from 2.5 to 11 million years ago (Boulding et al. 2009; Yazawa et al. 2008). These parasites are referred to herein as the Pacific and Atlantic forms of L. salmonis, respectively. In the southern hemisphere, Caligus rogercresseyi is the dominant species affecting salmonid aquaculture in Chile where the parasites were found on farmed salmon in $99 \%$ of the established cultured cages (Boxshall and Bravo 2000; Carvajal et al. 1998).

Lepeophtheirus and Caligus species are distinguished from each other based on morphological characters (Kabata 1979). The life cycle in $L$. salmonis has a total of ten developmental stages, while C. elongatus and C. rogercresseyi are similar but appear to lack pre-adult stages (Piasecki and MacKinnon 1995; González and Carvajal 2003). The host range of L. salmonis mainly includes salmonids but the parasite has also been reported from non- salmonid hosts, including sticklebacks, that co-occur with salmon (Jones et al. 2006). In contrast, some Caligus species have a broad host range of salmonids and nonsalmonids (Costello 2006; Johnson et al. 2004). Among its salmonid hosts, L. salmonis displays clear preferences, with heaviest infestations and greatest impacts occurring on Atlantic salmon (S. salar) and sea trout (Onchorhynchus trutta) followed by rainbow trout (Onchorhynchus mykiss), chinook (Onchorhynchus tshawytscha), and coho salmon (Onchorhynchus kisutch; Dawson et al. 1997; Fast et al. 2002; Johnson and Albright 1992). In contrast, C. rogercresseyi occurs in higher numbers on caged rainbow trout compared with Atlantic or coho salmon (González et al. 2000). Thus, while L. salmonis and Caligus species exhibit similar parasitic life history strategies, they display considerable differences in morphology, life cycle, and host range.

Another parasite, Lernaeocera branchialis belongs to the copepod family Pennellidae and is distantly related to the caligid copepods, and this species is commonly found on gadoids, particularly Atlantic cod (Gadus morhua) and haddock (Melanogrammus aeglefinus) in the North Atlantic Ocean and North Sea (Bricknell et al. 2006; Smith et al. 2007). This parasite has a negative impact on wild gadoids and is a potentially serious pathogen of farmed Atlantic cod (Smith et al. 2007). A compilation of genomic information on parasitic copepods is an important tool for understanding their biology as well as for the study of population genetics and control strategies.

In this study, we report on over 150,000 expressed sequence tags (ESTs) obtained from Pacific L. salmonis (49,672 new ESTs in addition to 14,994 previously reported ESTs), Atlantic L. salmonis (57,349 ESTs), C. clemensi (14,821 ESTs), C. rogercresseyi (32,135 ESTs), and $L$. branchialis (16,441 ESTs). These ESTs were assembled into complete or partial genes and annotated by comparisons to known proteins in public databases. In addition, whole mitochondrial $(\mathrm{mt})$ genome sequences of two Caligus species, C. clemensi and C. rogercresseyi, were determined and compared to each other and to L. salmonis. These studies show high levels of sequence divergence in nuclear and mtDNA genes. This report describes the production and characteristics of the largest genomic resource for copepods.

\section{Materials and Methods}

\section{EST Analysis}

Specimens belonging to the Pacific (British Columbia, Canada (BC)) and Atlantic forms of L. salmonis (Norway and New Brunswick, Canada), C. clemensi (BC), $C$. rogercresseyi (Chile), and L. branchialis (Scotland, UK) 
were collected and stored at $-80^{\circ} \mathrm{C}$ or in RNAlater (Invitrogen) until RNA extraction. Total RNA was extracted from whole bodies (from various life stages and both sexes) using TRIzol reagent (Invitrogen) and spin-column purified using RNeasy Mini kits (Qiagen). The purified RNAs were then quantified and quality checked by spectrophotometer (NanoDrop Technologies) and agarose gel, respectively. Approximately $1.0-3.0 \mu \mathrm{g}$ of total RNA was converted into cDNA and normalized and was directionally cloned into pAL 17.3 vector (Evrogen Co.).

Clones from each library were robotically arrayed in 384-well microtiter plates as detailed previously (Koop et al. 2008). Plasmid DNAs were extracted and sequenced on an ABI 3730 DNA analyzer (Applied Biosystems) with M13 forward and M13 reverse primers (L. salmonis and C. rogercresseyi) or with M13 forward and SP6 primers (C. clemensi and L. branchialis). These sequence primers are shown in supplemental Table 1. The resulting ESTs were assembled with CAP3 (Huang and Madan 1999) with default parameters. The assembled total contigs (clusters + singletons) were annotated using RPS-BLAST and BLASTX comparisons with the Conserved Domain Database (CDD) and SwissProt (Bairoch and Apweiler 1996), respectively. The best BLAST match ( $E$ value threshold of $1 \mathrm{E}^{-10}$ ) was used to identify contigs. Contigs that did not meet this threshold were annotated as "unknown."
Reference full-length cDNAs (FLcDNAs) were identified as detailed previously (Leong et al. 2010). A single clone containing an entire coding sequence (CDS) for a gene product is considered a reference FLcDNA.

Complete Mitochondrial Genome Sequences of C. clemensi and $C$. rogercresseyi

The total genomic DNAs were extracted from an adult male C. clemensi and C. rogercresseyi as previously described (Yazawa et al. 2008). A sample placed in 5\% Chelex-100 resin (Sigma) solution (5\% Chelex-100 resin, $0.2 \%$ SDS in TE, with proteinase $\mathrm{K}(100 \mu \mathrm{g} / \mathrm{ml}))$ was incubated for $30 \mathrm{~min}$ at $55^{\circ} \mathrm{C}$, and the proteinase $\mathrm{K}$ was then inactivated for $10 \mathrm{~min}$ at $90^{\circ} \mathrm{C}$. The sequence determination of the complete $C$. rogercresseyi $\mathrm{mt}$ genome was carried out as previously described (Yazawa et al. 2008). The PCR primer sets that were used were designed for 15 fragments (Supplemental Table 1) based on the EST sequences encoding mtDNA. PCR amplification was performed using $1.0 \mu \mathrm{l}$ of extracted total genomic DNA of C. rogercresseyi with an initial denaturation step of $2 \mathrm{~min}$ at $95^{\circ} \mathrm{C}$ and then 30 cycles as follows: $30 \mathrm{~s}$ of denaturation at $95^{\circ} \mathrm{C}, 30 \mathrm{~s}$ of annealing at $55^{\circ} \mathrm{C}$, and $3 \mathrm{~min}$ of extension at $72^{\circ} \mathrm{C}$. PCR products were cloned into pCR2.1 vector (TA Cloning Kit, Invitrogen) with the manufacturer's protocol, and each positive PCR product was sequenced as described above.

Table 1 Sea lice EST project summary

\begin{tabular}{|c|c|c|c|c|c|}
\hline & L. salmonis $(\mathrm{P})^{\mathrm{a}}$ & L. salmonis $(\mathrm{A})^{\mathrm{b}}$ & C. ciemensi & C. rogercresseyi & L. branchialis \\
\hline Number of clones ${ }^{c}$ & $38,880^{\mathrm{e}}$ & 51,607 & 7,680 & 19,200 & 8,448 \\
\hline Number of sequences ${ }^{\mathrm{d}}$ & $64,666^{\mathrm{e}}$ & $5734.9^{\mathrm{i}}$ & 14,821 & 32,135 & 16,441 \\
\hline Average trimmed EST length $(b p)^{\mathrm{f}}$ & 756 & 644 & 790 & 730 & 749 \\
\hline Number of contigs ${ }^{\mathrm{g}}$ & 11,922 & 9,113 & 4,392 & 8,251 & 4,239 \\
\hline Number of singletons & 4,186 & 5,145 & 1,662 & 3,106 & 2,199 \\
\hline Number of putative transcripts & 16,108 & 14,466 & 6,054 & 11,357 & 6,438 \\
\hline Maximum contig size (no. of ESTs) & 554 & 1482 & 15 & 34 & 21 \\
\hline Average contig size (no. of ESTs) & 4.0 & 4.0 & 2.5 & 2.8 & 2.6 \\
\hline Number of transcripts with BLAST hits ${ }^{\mathrm{h}}$ & 7,157 & 6,726 & 3,775 & 5,830 & 3,951 \\
\hline Percent with significant BLAST hits & $44.4 \%$ & $46.5 \%$ & $62.4 \%$ & $51.3 \%$ & $61.4 \%$ \\
\hline
\end{tabular}

${ }^{\mathrm{a}}$ L. salmonis Pacific form

${ }^{\mathrm{b}}$ L. salmonis Atlantic (Canada, Norway) form

${ }^{\mathrm{c}}$ Number of clones which from at least one sequence $\left(5^{\prime}\right.$ or $\left.3^{\prime}\right)$ was obtained

${ }^{\mathrm{d}}$ Number of 5' and 3' EST sequences obtained

${ }^{\mathrm{e}}$ Twenty-eight thousand thirty-two clones and 49,672 sequences were obtained from this study, while 5,760 clones and 14,994 sequences were previously reported (Yazawa et al. 2008)

${ }^{\mathrm{f}}$ Vector, low quality, and contaminating bacterial sequences are trimmed

${ }^{g}$ A contig (contiguous sequence) contains two or more ESTs

${ }^{\mathrm{h}}$ Number of transcripts that have a RPS-BLAST or BLASTX hit of less than $1 \mathrm{E}^{-10}$ to the Conserved Domain Database (CDD) or SwissProt databases

i $28 \mathrm{~K}$ sequences were obtained from F. Nilsen (University of Bergen, Norway) 
The entire mt genome for $C$. clemensi was amplified by a long PCR method for three long fragments $(5.4,5.0$, and $3.0 \mathrm{~kb}$ ) and by PCR as described above for one short fragment $(0.8 \mathrm{~kb})$. The three PCR fragments were amplified using the PCR primer sets shown in Supplemental Table 1 and by using Long PCR Enzyme mix (Fermentas) following the manufacturer's protocol. The long PCR amplification was performed using $100 \mathrm{ng}$ of extracted total genomic DNA of C. clemensi with an initial denaturation step of $2 \mathrm{~min}$ at $94^{\circ} \mathrm{C}$ and then a two-step PCR procedure $\left(40\right.$ cycles of $95^{\circ} \mathrm{C}$ for $10 \mathrm{~s}$ and $68^{\circ} \mathrm{C}$ for $7 \mathrm{~min}$ ), and $10 \mathrm{~min}$ of final extension. The three long PCR products were cloned into pCR-XL-TOPO vector (Invitrogen) with the manufacturer's protocol, and each positive PCR product was sequenced by primer walking (supplemental Table 1). The one short fragment was cloned into pCR2.1 vector and sequenced as described above.

Protein-coding and rRNA genes of $C$. clemensi and $C$. rogercresseyi were identified by alignment with the Pacific L. salmonis $\mathrm{mt}$ gene sequences (GenBank: EU288200). The majority of the tRNA genes was identified using tRNAscan-SE 1.21(Lowe and Eddy 1997), using the same parameters as described by Tjensvoll et al. (2005). The remaining tRNA genes were identified based on the sequence homology with $L$. salmonis tRNA sequences.

Pair-wise Kimura two-parameter (K2P) distances (Kimura 1980) of 16S rRNA and coxlgenes for $C$. clemensi, $C$. rogercresseyi, and Pacific L. salmonis were calculated in MEGA5 (Tamura et al. 2007), with default settings.

\section{Results and Discussion}

\section{EST Analysis and Comparison of the Nuclear Genes}

Normalized cDNA libraries were constructed for Pacific $L$. salmonis, Atlantic L. salmonis, C. clemensi, C. rogercresseyi, and L. branchialis. The 114,967 clones obtained from these cDNA libraries $(28,032$ Pacific L. salmonis, 51,607 Atlantic L. salmonis, 7,680 C. clemensi, 19,200 C. rogercresseyi, and 8,448 L. branchialis) were sequenced with M13 forward and M13 reverse ( $L$. salmonis and $C$. rogercresseyi) or with M13 forward and SP6 primers $(C$. clemensi and L. branchialis). A summary of the EST project is shown in Table 1. From these clones, 153,977 high-quality ESTs were obtained from Pacific L. salmonis (49,672 ESTs), Atlantic L. salmonis (57,349 ESTs), C. clemensi (14,821 ESTs), C. rogercresseyi (32,135 ESTs), and $L$. branchialis $(16,441$ ESTs). The average trimmed length of these ESTs was $734 \mathrm{bp}$. These EST sequences are available in GenBank.

The 49,672 Pacific L. salmonis ESTs obtained in this study along with 14,994 Pacific L. salmonis ESTs from our previous study (Yazawa et al. 2008) were assembled into 11,922 contigs and 4,186 singletons (16,108 putative transcripts). There is a total of 14,466 putative transcripts for Atlantic L. salmonis, 6,054 for C. clemensi, 11,357 for $C$. rogercresseyi, and 6,438 for $L$. branchialis. These putative transcripts were annotated using RPS-BLAST and BLASTX comparisons with the CDD and SwissProt (Bairoch and Apweiler 1996), respectively. The best match ( $E$ value threshold of $1 \mathrm{E}^{-10}$ ) was used to identify putative transcripts. Of the 16,108 Pacific $L$. salmonis putative transcripts, 7,157 (44.4\%) matched at least one entry in the databases while the others remain unidentified. Similarly, 6,726 (46.5\%) Atlantic L. salmonis, 3,775 (62.4\%) C. clemensi, 5,830 (51.3\%) C. rogercresseyi, and 3,951 (61.4\%) L. branchialis putative transcripts have significant BLAST hits (Table 1).

A collection of reference FLcDNA clones is an important resource for identifying genes, determining their structural features and for experimental analysis of gene functions. Possible reference FLcDNAs were defined as having an entire open reading frame (ORF) corresponding to a full-length protein and were identified as described previously (Leong et al. 2010). Using an $E$ value filter of $E \leq 10^{-5}$, the top ten SwissProt high-scoring segment pairs (HSPs) from BLASTX for each putative transcript were analyzed in succession to identify the correct ORF. Of the 16,108 Pacific L. salmonis putative transcripts, 1,435 transcripts were identified as possible FLcDNAs. There are 1,086 Atlantic L. salmonis FLcDNAs, 1,223 C. clemensi FLcDNAs, and 1,574 C. rogercresseyi FLcDNAs. These reference FLcDNAs were submitted to NCBI's FLIC database.

A relational database with an intuitive web interface was developed to process and display the large quantities of EST data, their assemblies, and their associated annotation information (Fig. 1). This interface provides the ability to search using sequence data, identifiers, accession numbers, and descriptive keywords. The BLAST search allows users to perform homology searches with sequences of interest, identifying potential transcripts names, and then visualizing these sequences and EST alignments. These EST contigs have predicted ORFs and BLASTX HSPs displayed in a single view. This database contributes to the identification and analysis of proteins and to the development of microarrays for gene expression analyses.

Fig. 1 Screenshot of sea lice EST contig summary and search tools. The top panel allows users to perform homology searches for sequences of interest. The second provides the ability to search using sequence data, identifiers, accession numbers, and descriptive keywords. The third to seventh panels show a summary of the EST clustering results of $C$. clemensi, $C$. rogercressyi, Pacific $L$. salmonis, Atlantic L. salmonis, and L. branchialis, respectively 


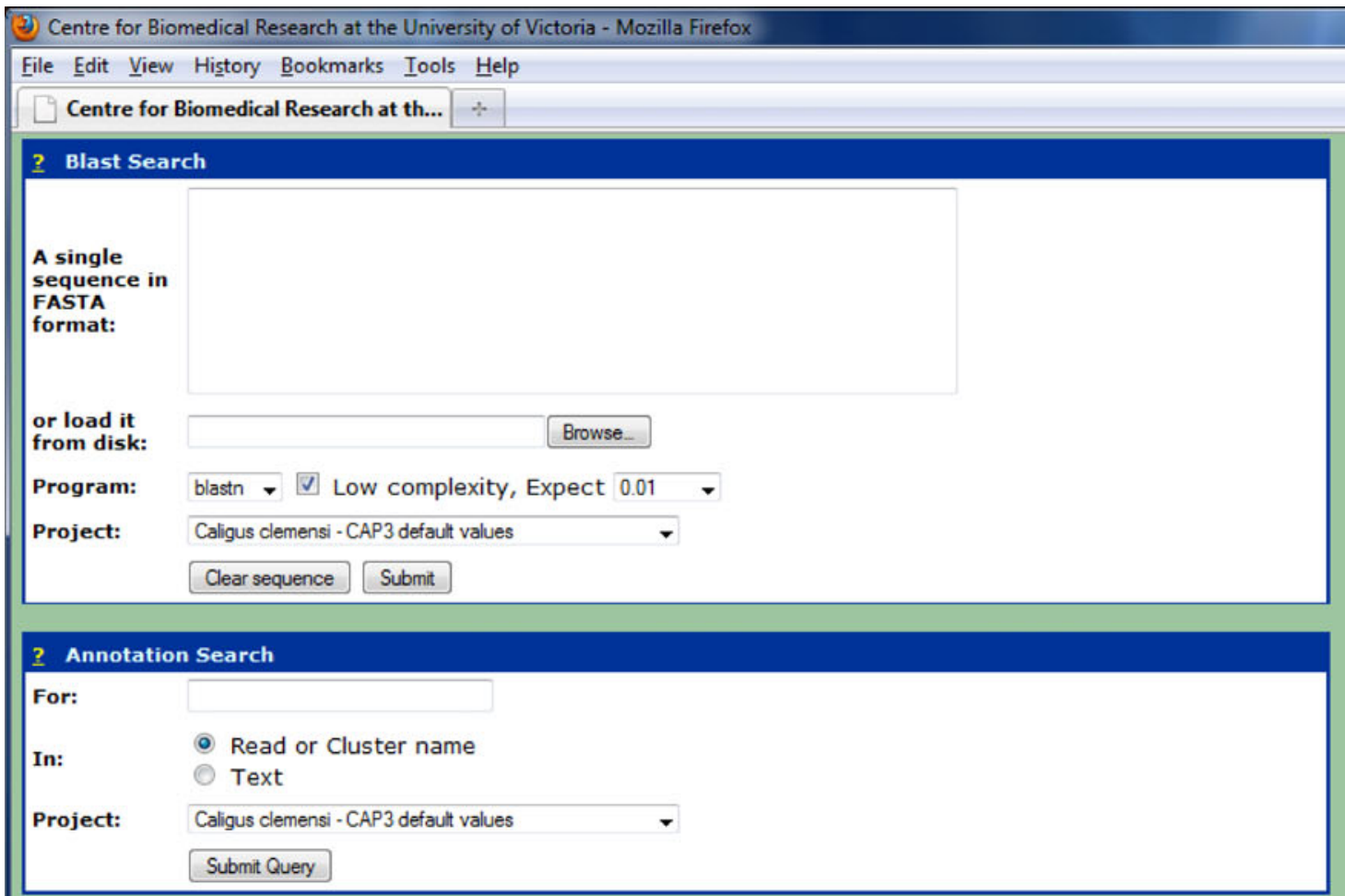

- home / [organism summary]

\section{Caligus clemensi [Sea lice] clustering projects}

\begin{tabular}{|c|c|c|c|c|c|c|c|c|}
\hline Created & Name & Description & Clusters $(>=2)$ & Clusters $(>=3$ ) & Singletons & $\begin{array}{l}\text { Total } \\
\text { Transcripts }\end{array}$ & IDs & $\begin{array}{l}\text { Total } \\
\text { ESTs }\end{array}$ \\
\hline $\begin{array}{l}\text { October } \\
27 \text { th, } 2008\end{array}$ & $\begin{array}{l}\text { Caliqus clemensi } \\
\text { - CAP3 default } \\
\text { values }\end{array}$ & $\begin{array}{l}\text { CAP3 assembly of Caligus } \\
\text { clemensi sequences (default } \\
\text { values) }\end{array}$ & $\underline{4392}$ & 1640 & $\underline{1662}$ & $\underline{6054}$ & $\begin{array}{l}\frac{3775}{(C D D} \\
\text { swissprot) }\end{array}$ & $\underline{14821}$ \\
\hline
\end{tabular}

\section{Caligus rogercresseyi [Sea lice] clustering projects}

\begin{tabular}{|c|c|c|c|c|c|c|c|c|}
\hline Created & Name & Description & Clusters $(>=2)$ & Clusters $(>=3)$ & Singletons & $\begin{array}{l}\text { Total } \\
\text { Transeripts }\end{array}$ & IDs & $\begin{array}{l}\text { Total } \\
\text { ESTs }\end{array}$ \\
\hline $\begin{array}{l}\text { May 8th, } \\
2008\end{array}$ & $\begin{array}{l}\frac{\text { Caliqus }}{\text { rogercressevi - }} \\
\frac{\text { CAP3 default }}{\text { values }}\end{array}$ & $\begin{array}{l}\text { CAP3 assembly of Caligus } \\
\text { rogercresseyi sequences (default } \\
\text { values) }\end{array}$ & $\underline{8251}$ & 3768 & $\underline{3106}$ & $\underline{11357}$ & $\begin{array}{l}\frac{5830}{(\mathrm{CDD}} \\
\text { swissprot) }\end{array}$ & $\underline{32135}$ \\
\hline
\end{tabular}

\section{Lepeophtheirus salmonis [Salmon louse] clustering projects}

\begin{tabular}{|c|c|c|c|c|c|c|c|c|}
\hline Created & Name & Description & Clusters $(>=2)$ & Clusters $(>=3$ ) & Singletons & $\begin{array}{l}\text { Total } \\
\text { Transeripts }\end{array}$ & IDs & $\begin{array}{l}\text { Total } \\
\text { ESTs }\end{array}$ \\
\hline
\end{tabular}

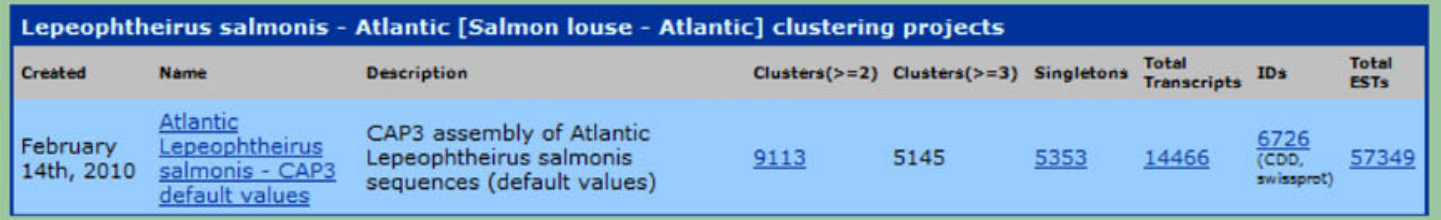

\begin{tabular}{|c|c|c|c|c|c|c|c|c|}
\hline Created & Name & Description & Clusters(>=2) & Clusters(> $=3$ ) & Singletons & $\begin{array}{l}\text { Total } \\
\text { Transcripts }\end{array}$ & IDs & $\begin{array}{l}\text { Total } \\
\text { ESTs }\end{array}$ \\
\hline $\begin{array}{l}\text { June 18th, } \\
2009\end{array}$ & $\begin{array}{l}\text { Lernaeocera } \\
\text { branchialis - } \\
\text { CAP3 default } \\
\text { values }\end{array}$ & $\begin{array}{l}\text { CAP3 assembly of Lernaeocera } \\
\text { branchialis sequences (default } \\
\text { values) }\end{array}$ & $\underline{4239}$ & 1891 & $\underline{2199}$ & $\underline{6438}$ & $\frac{\frac{3951}{\text { (CDD. }}}{\text { swissprot) }}$ & $\underline{16441}$ \\
\hline
\end{tabular}


Sequence similarities and putative transcripts were compared among the nuclear genes of the five copepods (Pacific L. salmonis, Atlantic L. salmonis, C. clemensi, C. rogercresseyi, and $L$. branchialis) by BLASTN for nucleotide (nt) sequences and tBLASTX for amino acid (aa) sequences (Table 2). We previously reported that a total of 155 nuclear genes from Pacific and Atlantic L. salmonis showed an average of $96.8 \%$ nt identity over an average of 756 bp (Yazawa et al. 2008). In this study, a total of 8,121 nucleotide and 8,827 translated aa sequences matched between the Pacific and Atlantic L. salmonis putative transcripts. These sequences showed an average of $96 \%$ identity at the nt level over an average of 626 bp and $88 \%$ at the aa level over an average of 187 aa (Table 2). Nuclear gene sequences were quite different not only between the genera Caligus and Lepeophtheirus (81-82\% nt, 70-72\% aa identities), but also between the two Caligus species ( $83 \%$ nt, $71 \%$ aa identities; Table 2). The range of nuclear gene sequence divergence was quite similar among these species (17-19\% nt and 28-30\% aa sequence divergences). As expected, nucleotide sequences of L. branchialis, the only species examined from the family Pennellidae, were very different from the caligid sequences: only $4-6 \%$ of the total queries (254-405 sequences) matched the nuclear genes of the four other copepods. We speculate that the matched genes are conserved among copepods and therefore we could not determine the divergence between $\mathrm{nt}$ sequences of $L$. branchialis and the four caligid copepods. However, the 2,634-3,375 translated aa sequences of $L$. branchialis (44-52\% of query sequences) did show significant matches with sequences of the four other copepods. These translated aa sequences showed 59-62\% identities over averages of 121-132 aa (Table 2). Although these comparisons provide only a very rough estimate of overall sequence similarity, they clearly indicate a high level of sequence divergence among these copepods nuclear genes.

Mitochondrial Genome Sequences of L. salmonis, $C$. clemensi, and C. rogercresseyi

Metazoan mt genomes typically range between 15 and $20 \mathrm{~kb}$ in size, containing 37 genes: 13 protein-encoding genes (PCGs), 22 transfer RNA (tRNA) genes, two ribosomal RNA (rRNA) genes and a major non-coding region (NCR; Boore 1999). In this study, whole mt genome sequences of two Caligus species, C. clemensi and $C$. rogercresseyi, were determined. The sizes of the entire $\mathrm{mt}$ genomes were $13,440 \mathrm{bp}$ for $C$. clemensi [Genbank: HQ157566] and 13,468 bp for C. rogercresseyi [Genbank: HQ157565], and thus, these mt genomes are the shortest among 57 crustacean $\mathrm{mt}$ genomes (average length: 15,785 bp) reported so far (Genbank: November 2010).
There are two reasons for the small size of these $\mathrm{mt}$ genomes. First, the major NCRs of the C. clemensi (104 bp) and $C$. rogercresseyi (129 bp) $\mathrm{mt}$ genomes were much shorter than that of L. salmonis (Pacific form, 1,441 bp; Atlantic form, 2,146 bp) and that of other crustaceans (average length, $875 \mathrm{bp}$ ), except for that of the amphipod Metacrangonyx longipes (76 bp; Bauzà-Ribot et al. 2009). Second, while both Caligus mt genomes contained the typical set of 12 protein-encoding, 21 tRNA and two rRNA genes found in other animal $\mathrm{mt}$ genomes, both $\mathrm{mt}$ genomes lacked the PCG, nad4L, and a tRNA gene, $\operatorname{trn} L_{2}$ (CUN).

Interestingly, the $C$. clemensi $\mathrm{mt}$ genome is adenine and thymine (A + T)-rich (PCG, 74.5\%; whole genome, 75.6\%) compared to C. rogercresseyi and L. salmonis (PCG, 63.664.9\%; whole genome, 65.2-66.5\%; Supplemental Table 2). In crustaceans, the mt genomic $\mathrm{A}-\mathrm{T}$ content values range from $60.9 \%$ for Ligia oceanica (Isopoda; Kilpert and Podsiadlowski 2006) to $77.8 \%$ for Argulus americanus (Branchiura; Lavrov et al. 2004). The reason for the variability in $\mathrm{A}-\mathrm{T}$ richness within the mitochondrial genome among taxa is not clear.

Like the nuclear genes, the mtDNA gene sequences also exhibited large divergence, not only between L. salmonis and the two Caligus species (66.7-68.8\% nt and 64.2$65.4 \%$ aa identities), but also between the two Caligus species $(68.8 \% \mathrm{nt}$ and $63.6 \%$ aa identities). The range of mtDNA sequence divergence was quite similar among the three caligid copepods. The percent nt and aa identities among the L. salmonis, C. clemensi, and C. rogercresseyi sequences are $63.6-68.8 \%$ (Table 3 ). The coxl gene is the most conserved PCG among the three mt genomes (79.1$82.6 \%$ nt and $91.2-94.1 \%$ aa identities), while nad2, nad4, nad5, and nad6 exhibit a large sequence divergence (56.1$62.2 \%$ nt and $40.0-51.9 \%$ aa identities; Table 3 ).

Hebert et al. (2003) reported that coxl divergences among the 13,320 species in the animal kingdom ranged from a low of $0.0 \%$ to a high of $53.7 \%$ and the mean divergence value of $11.3 \%$. The coxl divergences in the Crustacea showed the mean species divergence value of $15.4 \%$ (Hebert et al. 2003). Interestingly, our present study showed that the coxl divergences among the three caligid copepods were higher than the mean divergence value of Crustacea. The coxl interspecific divergence between $C$. clemensi and C. rogercresseyi is $20.2 \%$ and between the genera Caligus and Lepeoptheirus 26.0\%. Øines and Schram (2008) compared among the cox fragment (a total 504 aligned base pairs) of 18 caligid copepods and the $16 \mathrm{~S}$ rRNA fragment (a total of 438 aligned base pairs) of 11 caligid copepods. They found that an average K2P distance of coxl were 0.218 and those of $16 \mathrm{~S}$ rRNA were 0.221 (Øines and Schram 2008). In the present study, the K2P distance of coxl (a total of 1,539 aligned base pairs) among the L. salmonis, C. clemensi, and C. rogercresseyi is $0.202-$ 


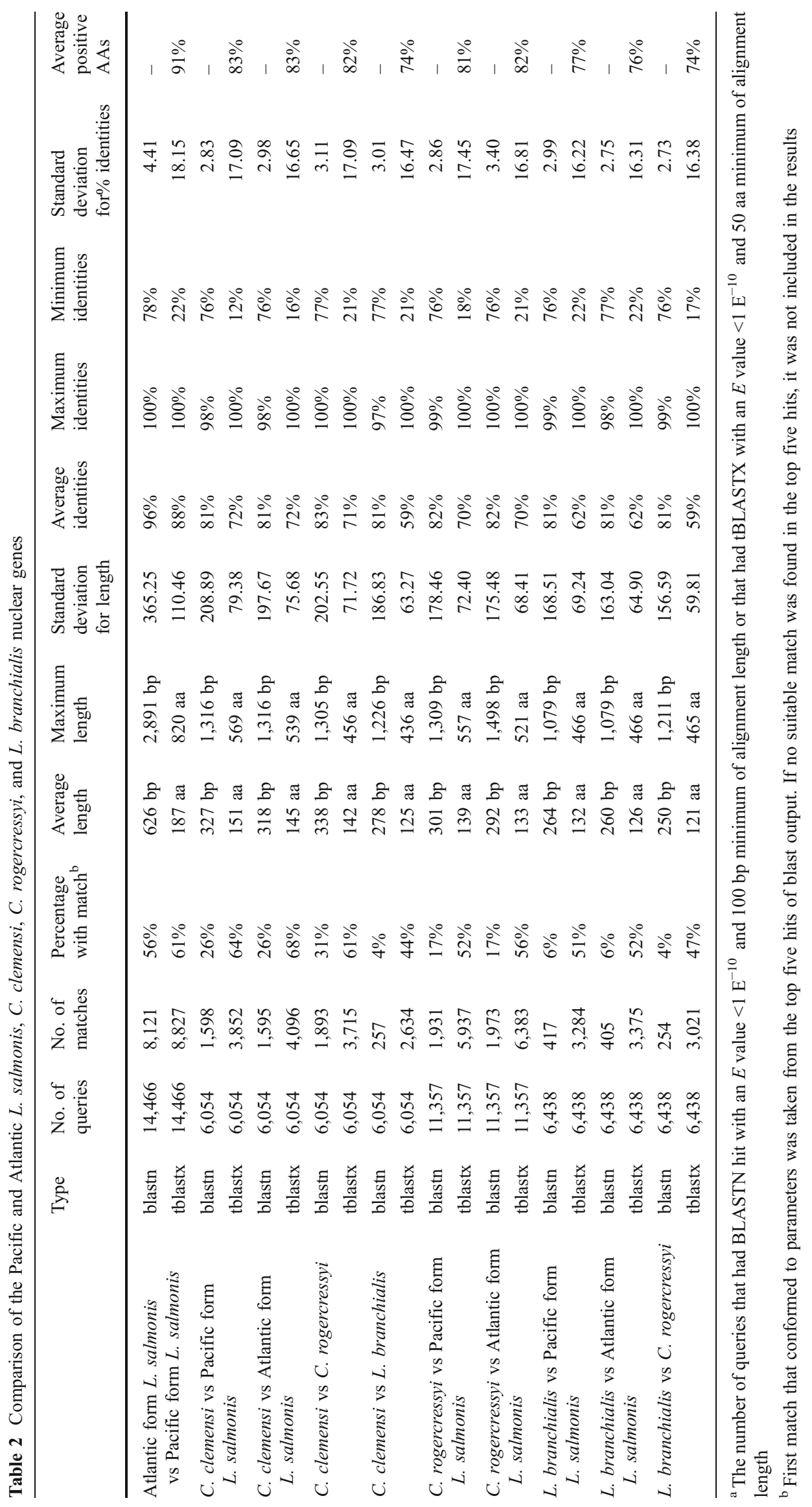


Table 3 Comparison of the L. salmonis, C. clemensi, and C. rogercressyi mtDNA genes

\begin{tabular}{|c|c|c|c|c|c|c|c|c|}
\hline \multirow[t]{2}{*}{ Genes } & \multicolumn{4}{|c|}{ In nucleic sequence $(\%)$} & \multicolumn{4}{|c|}{ In deduced amino acid sequence $(\%)$} \\
\hline & $\begin{array}{l}\text { Pacific form } \\
\text { L. salmonis } \\
\text { vs } C \text {. } \\
\text { clemensi }\end{array}$ & $\begin{array}{l}\text { Pacific form } \\
\text { L. salmonis } \\
\text { vs } C \text {. } \\
\text { rogercressyi }\end{array}$ & $\begin{array}{l}C . \text { clemensi } \\
\text { vs } C \text {. } \\
\text { rogercressyi }\end{array}$ & $\begin{array}{l}\text { Atlantic form } L \text {. } \\
\text { salmonis vs } \\
\text { Pacific form } L \text {. } \\
\text { salmonis }\end{array}$ & $\begin{array}{l}\text { Pacific form } \\
\text { L. salmonis } \\
\text { vs } C \text {. } \\
\text { clemensi }\end{array}$ & $\begin{array}{l}\text { Pacific form } \\
\text { L. salmonis } \\
\text { vs } C \text {. } \\
\text { rogercressyi }\end{array}$ & $\begin{array}{l}\text { C. clemensi } \\
\text { vs } C \text {. } \\
\text { rogercressyi }\end{array}$ & $\begin{array}{l}\text { Atlantic form } L \text {. } \\
\text { salmonis vs } \\
\text { Pacific form } L \text {. } \\
\text { salmonis }\end{array}$ \\
\hline $\operatorname{rrnS}$ & 77.2 & 76.4 & 74.9 & 98.8 & - & - & - & - \\
\hline $\operatorname{rrnL}$ & 68.3 & 67.2 & 71.2 & 96.9 & - & - & - & - \\
\hline $\operatorname{atp} 8^{\mathrm{a}}$ & 72.0 & 67.7 & 72.0 & 96.8 & - & - & - & - \\
\hline atp6 & 63.9 & 65.4 & 65.3 & 91.9 & 61.5 & 66.7 & 60.3 & 95.9 \\
\hline cob & 71.0 & 70.8 & 71.3 & 93.7 & 79.7 & 80.3 & 77.6 & 98.5 \\
\hline $\operatorname{coxi}$ & 79.1 & 77.9 & 82.6 & 92.9 & 90.8 & 91.2 & 94.1 & 99.2 \\
\hline $\operatorname{cox} 2$ & 76.6 & 75.7 & 78.5 & 93.5 & 75.4 & 81.2 & 85.5 & 100.0 \\
\hline $\operatorname{cox} 3$ & 73.2 & 71.7 & 72.4 & 92.0 & 75.6 & 82.5 & 79.2 & 98.2 \\
\hline nadi & 72.2 & 71.6 & 70.5 & 92.8 & 69.2 & 75.3 & 66.8 & 96.9 \\
\hline $\operatorname{nad} 2$ & 57.9 & 57.8 & 59.3 & 90.9 & 40.5 & 45.8 & 43.2 & 94.8 \\
\hline $\operatorname{nad} 3$ & 68.5 & 57.8 & 65.0 & 91.6 & 64.1 & 54.7 & 59.3 & 97.5 \\
\hline nad4 & 61.9 & 58.8 & 58.7 & 91.2 & 49.1 & 49.3 & 44.0 & 92.6 \\
\hline $\operatorname{nad} 4 L^{b}$ & N.A. & N.A & N.A. & 94.3 & - & - & - & 97.3 \\
\hline nad5 & 62.2 & 58.8 & 61.8 & 90.7 & 51.9 & 50.4 & 49.4 & 95.5 \\
\hline nad6 & 59.6 & 56.1 & 59.1 & 93.8 & 48.3 & 42.0 & 40.0 & 97.3 \\
\hline Average & 68.8 & 66.7 & 68.8 & 93.5 & 64.2 & 65.4 & 63.6 & 97.0 \\
\hline
\end{tabular}

${ }^{\text {a }}$ Comparisons of amino acid sequences of atp 8 genes were not conducted because these sequences are very short in size ( 31 aa)

${ }^{\mathrm{b}}$ nad4L genes are absent in the two Caligus species

0.270 (Supplemental Table 3), which is similar to an average K2P distance found by Øines and Schram (2008). However, the 16S rRNA among the three copepods showed a very high genetic distance. The K2P distance of the $16 \mathrm{~S}$ rRNA (a total of 1,085 aligned base pairs) were 0.333 between $C$. clemensi and C. rogercresseyi and 0.422 (Supplemental Table 3). These molecular distance values support an ancient separation between $C$. clemensi and $C$. rogercresseyi as well as between Lepeoptheirus and Caligus.

In our previous study, a molecular clock based on $16 \mathrm{~S}$ rRNA and calibrated by copepod data suggested that the forms of L. salmonis existing in the Pacific and Atlantic Oceans evolved from a common ancestor following a separation that occurred from 4.6-11 million years ago (Yazawa et al. 2008). In this study, the molecular estimates of the age of divergence between the L. salmonis (Pacific) and the two Caligus species were calculated based on the $16 \mathrm{~S}$ rRNA gene using the same method as previously reported (Yazawa et al. 2008). The results suggest that the separation between the L. salmonis (Pacific) and the two Caligus species occurred approximately 45-113 million years ago (Table 4). In addition, the separation between the two Caligus species was estimated to have occurred $37-$ 87 million years ago (Table 4). Salmonids are believed to have evolved from an ancestor in which a whole genome duplication event occurred 25-100 million years ago (Ohno 1970). Thus, our present results suggest that the $L$. salmonis and C. clemensi have been in existence for 45-106 million years and that parasitic association with salmonids is likely also quite ancient (Table 4).

The order of the genes in the two Caligus mt genomes is identical despite extensive sequence divergence. In contrast, the order of genes in the two Caligus mt genomes is quite different from that in the L. salmonis $\mathrm{mt}$ genome. The gene arrangement in the region between nad4 and $\operatorname{trn} L_{1}$ (UUR; approximately $10 \mathrm{~kb}$ ) is well conserved between $L$. salmonis and the Caligus species. However, the gene arrangements adjacent to their control regions (CRs) are very distinct, and the Caligus $\mathrm{mt}$ genomes show a novel gene arrangement (Fig. 2). The region around the CR is more prone to gene rearrangement in both vertebrate (Macey et al. 1997) and invertebrate (Dowton and Austin 1999) $\mathrm{mt}$ genomes. In the L. salmonis $\mathrm{mt}$ genomes, the region between $\operatorname{trn} K_{2}$ and $\operatorname{trnR}$ (six tRNA and atp6 genes) is in a row (Tjensvoll et al. 2005; Yazawa et al. 2008). However, in the Caligus mt genomes, this region is separated by $r r n S$-nad6-trnA-trnK ${ }_{1}$-trnQ-trnT-cytb-CR, and divided into $\operatorname{trn} K_{2}$-trnN-trnG-trnV and atp6-trnY-trnR (trnY also had a position change; Fig. 2). As mentioned above, the nad $4 L$ and $\operatorname{trn} L_{2}$ (CUN) genes are absent in the Caligus $\mathrm{mt}$ genomes. These two genes normally reside in this region 
Table 4 Ranges of 16S rRNA gene divergence based on Kimura two-parameter distance and crustacean molecular clock calibrations

\begin{tabular}{|c|c|c|c|c|c|}
\hline & \multirow[t]{2}{*}{ Distance (K2P) } & \multicolumn{4}{|c|}{ Divergence Range (Myr) } \\
\hline & & Ano & Fid & Gra (low) & Gra (high) \\
\hline Pacific form L. salmonis vs. C. clemensi & 0.405 & 106.2 & 45.0 & 62.3 & 46.0 \\
\hline Pacific form L. salmonis vs. C. rogercressyi & 0.431 & 113.0 & 47.8 & 66.2 & 48.9 \\
\hline C. clemensi vs. C. rogercressyi & 0.333 & 87.4 & 37.0 & 51.2 & 37.8 \\
\hline
\end{tabular}

The values for "Distance" are the Kimura two-parameter (K2P) distance between the species. Rates of molecular evolution used for the 16S rRNA gene include $0.38 \% \mathrm{~K} 2 \mathrm{P} /$ million year (Myr) for anomurans (Ano; Cunningham et al. 1992), 0.90\% K2P/Myr for fiddler crabs (Fid; Sturmbauer et al. 1996), and 0.65 (low) $-0.88 \%$ (high) K2P/Myr obtained from grapsid crabs (Gra; Schubart et al. 1998)

and have probably been lost due to rearrangement. It is likely that this rearrangement event also has led to the trimming of their CRs in the two Caligus mt genomes.

In the $\mathrm{mt}$ genomes of most animals, nad $4 L$ and atp 8 are located together with nad4 and atp6, respectively (nad4Lnad4 and atp8-atp6), and nad4L-nad4 and atp8-atp6 are translated from a single mRNA (Amalric et al. 1978; Berthier et al. 1986). In contrast, several genes separate nad4 and nad $4 L$ in the mt genomes of L. salmonis and in the $\mathrm{mt}$ genomes of all copepods characterized so far: Tigriopus japonicas (Machida et al. 2002), Tigriopus californicus (Burton et al. 2007), Paracyclopina nana (Ki et al. 2009), and the partially sequenced mt genomes of Eucalanus bungii and Neocalanus cristatus (Machida et al. 2004). The atp6 and atp 8 are also separated in the two Caligus species and in L. salmonis (Fig. 2). In addition, it has been reported that atp 8 is absent in the $\mathrm{mt}$ genome of $P$. nana (Ki et al. 2009). Thus, it is most likely that these separations of nad4-nad4L and atp6-atp 8 occurred during copepod evolution and led to the loss of nad4L in the two Caligus species and to the loss of atp 8 in the P. nana.

In summary, the mtDNA genes of the two Caligus species showed high levels of sequence divergence (Table 3). The $\mathrm{A}+\mathrm{T}$ content is also quite different between

\section{Caligus clemensi $(13.5 \mathrm{~kb})$}

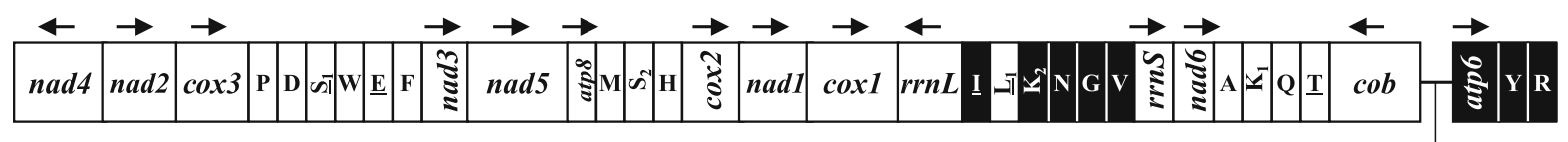

Caligus rogercresseyi $(13.5 \mathrm{~kb})$

(104 bp)

$C R$

(129 bp)

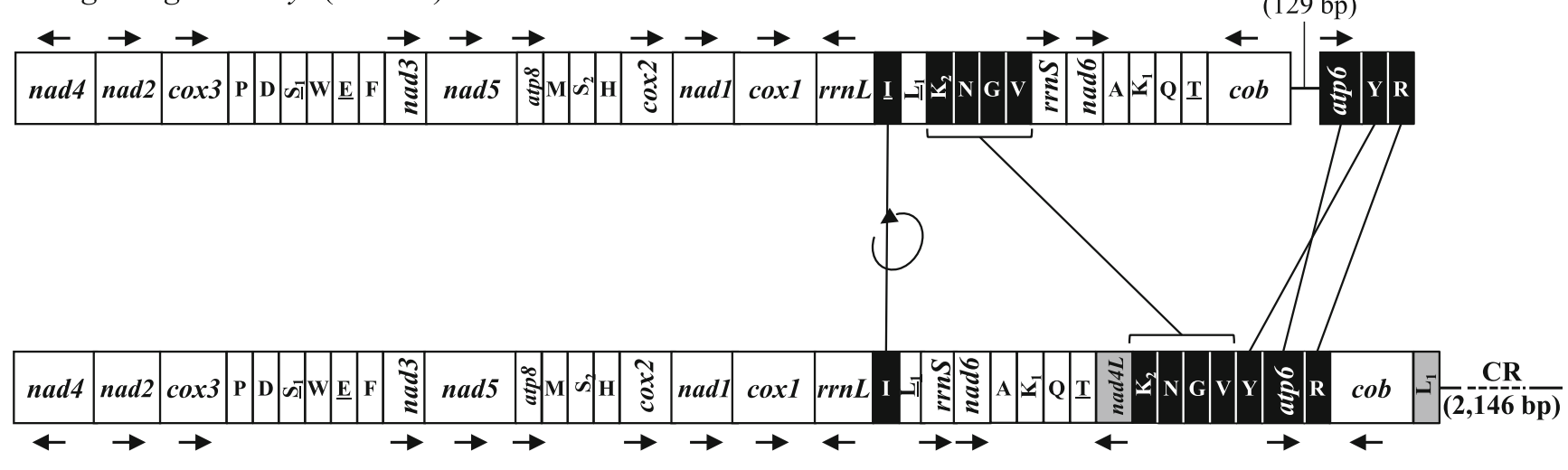

Lepeophtheirus salmonis: Atlantic form (15.4 kb), Pacific form (16.1 kb)
Fig. 2 Genomic organization of the C. clemensi $(13,440 \mathrm{bp})$ and the C. rogercressyi $(13,468 \mathrm{bp}) \mathrm{mt}$ genomes. The complete $\mathrm{mt}$ genomes of the Atlantic $(15,445 \mathrm{bp})$ and Pacific $(16,148 \mathrm{bp})$ L. salmonis were previously reported, and these $\mathrm{mt}$ genomes are identical in gene organization (Tjensvoll et al. 2005; Yazawa et al. 2008). Boxes represent mtDNA genes. tRNA genes are denoted by the single letter amino acid code, and an underline indicates tRNA genes located on negative strand. $r r n L$ and $r r n S$ refer to $16 \mathrm{~S}$ and 12S rRNA; coxl, $\operatorname{cox} 2$, and $\operatorname{cox} 3$ refer to cytochrome oxidase subunit I, II, and III; $c o b$ refers to cytochrome $\mathrm{b}$; nadl-6 and nad4L refer to NADH dehydrogenase subunits $1-6$ and 4 L, atp 6 and atp 8 refer to ATP synthase subunits 6 and 8 , respectively, and $C R$ refers to control region. Transcription directions for the protein-coding and rRNA genes are shown by arrowheads 
the two Caligus mt genomes (Supplemental Table 2). In addition, the orders of the genes in the two Caligus $\mathrm{mt}$ genomes are identical to each other, but different from the order in the L. salmonis mt genome (Fig. 2).

\section{Sea Lice as Ectoparasite Model System}

Since parasites by definition depend on a live host for growth and survival, in vitro culture system is typically very difficult to establish. Although procedures for experimental infections are established for some parasitic species, manipulation of the parasites may still be very difficult since removing them from the host is lethal for the parasite in general. Sea lice have life cycle features that make them promising as a model system. The life cycle features, consisting of both free-living larval developmental stages and pre-adults and adult stages that can move unrestricted on host surface, enable manipulation of these parasites. For L. salmonis, recent advances in larval production systems and infection procedures (see Hamre et al. 2009) have been crucial for the establishment of defined laboratory strains of the salmon louse with different properties (e.g., drug-resistant strains, inbred strains). Stable and predictable production conditions further enables specific breeding to create various types of hybrids (e.g., susceptible and drug-resistant family groups). The improvement of rearing facilities has been a crucial facilitator for establishment of RNAi in L. salmonis (Dalvin et al. 2009). Systemic RNAi is easily achieved in pre-adult or adult lice by injection of dsRNA in the animal. In addition, soaking free-living larval stages (e.g., copepodids) in dsRNA enables RNAi in copepodids (Campell et al. 2009). In addition, the genomes of both the Pacific and Atlantic variants of $L$. salmonis are currently being sequenced and together with the present cDNA resources this will open up for a new avenue in sea lice research. There is a wide diversity of arthropod parasites and good experimental parasite model systems are scarce, and we anticipate that experimental studies on salmon louse and other sea lice species will contribute to increase our knowledge about ectoparasites in general, particularly when more parasite genomes become available.

\section{Conclusions}

We sequenced over 150,000 ESTs from Pacific L. salmonis $(49,672$ new ESTs in addition to 14,994 previously reported ESTs), Atlantic L. salmonis (57,349 ESTs), C. clemensi $(14,821$ ESTs), C. rogercresseyi (32,135 ESTs), and $L$. branchialis (16,441 ESTs; Table 1). A relational database with an intuitive web interface was developed to process and display the large quantities of EST data, their assemblies and associated annotation information, as well as possible full-length gene information (Fig. 1). This database provides a novel resource for the study of sea louse biology, population genetics, and control strategies. This genomic resource represents the largest compilation of any copepod species and provides the material basis for the development of a $38 \mathrm{~K}$ microarray that can be used in conjunction with our existing salmon $44 \mathrm{~K}$ microarray to study host-parasite interactions at the molecular level.

The nuclear genes showed a high level of sequence divergence among the caligid copepods examined: $L$. salmonis, C. clemensi, C. rogercresseyi, and L. branchialis (Table 2). In addition, whole $\mathrm{mt}$ genome sequences of two Caligus species, C. clemensi $(13,440 \mathrm{bp})$ and C. rogercresseyi $(13,468 \mathrm{bp})$, were determined and compared. The L. salmonis, C. clemensi, and C. rogercresseyi mtDNA genes also exhibited extensive sequence divergence, ranging among these species from 66.7 to $68.8 \% \mathrm{nt}$ and from $63.6 \%$ to $65.4 \%$ aa identities (Table 3). Both nuclear and mtDNA genes showed very high levels of sequence divergence between these ectoparastic copepods which suggested that they have been in existence for 37 113 million years and that parasitic association with marine organisms is likely also quite ancient. However, while the order of the genes in the two Caligus mt genomes is the same, they are different from L. salmonis (Fig. 2). The large sequence divergence observed among these copepods may help to explain an extensive variety of morphology, life history, and host association in copepods.

Acknowledgments This project (GiLS - Genomics in Lice and Salmon) was supported by Genome BC, Microtek Intl., Marine Harvest, Mainstream Canada, Greig Seafoods, and the University of Victoria. We would like to thank Rob Holt (Head of Sequencing, Genome Sciences Centre, Vancouver, BC, Canada), Richard Moore (Sequencing Group Leader, Genome Sciences Centre), Sarah Munro, Mike Mayo, and Susan Wagner (Genome Sciences Centre) for plating and sequencing. We also would like to thank John Burka (University of P.E.I., Canada), Frank Nilsen, and Heidi Kongshaug (University of Bergen, Norway) for Atlantic forms of L. salmonis; the Salmones Maullin Company (Chile) for C. rogercresseyi; Brendan Conners (Salmon Coast Field Station, Simoom Sound, BC, Canada) for $C$. clemensi; and James Bron and Sarah Barker (University of Stirling, Scotland, UK) for L. branchialis.

Open Access This article is distributed under the terms of the Creative Commons Attribution Noncommercial License which permits any noncommercial use, distribution, and reproduction in any medium, provided the original author(s) and source are credited.

\section{References}

Amalric F, Merkel C, Gelfand R, Attardi G (1978) Fractionation of mitochondrial RNA from HeLa cells by high-resolution electrophoresis under strongly denaturing conditions. J Mol Biol 118:125 
Bairoch A, Apweiler R (1996) The SWISS-PROT protein sequence data bank and its new supplement TREMBL. Nucl Acids Res 24:21-25

Bauzà-Ribot MM, Jaume D, Juan C, Pons J (2009) The complete mitochondrial genome of the subterranean crustacean Metacrangonyx longipes (Amphipoda): A unique gene order and extremely short control region. Mitochondrial DNA 20:88-99

Beamish R, Wade J, Pennell W, Gordon E, Jones S, Neville C, Lange $\mathrm{K}$, Sweeting R (2009) A large, natural infection of sea lice on juvenile Pacific salmon in the Gulf Islands area of British Columbia, Canada. Aquaculture 297:31-37

Beamish RJ, Neville CM, Sweeting RM, Ambers N (2005) Sea lice on adult Pacific salmon in the coastal waters of Central British Columbia, Canada. Fish Res 76:198-208

Berthier F, Renaud M, Alziari S, Durand R (1986) RNA mapping on Drosophila mitochondrial DNA: precursors and template strands. Nucl Acids Res 14:4519-4533

Boore JL (1999) Animal mitochondrial genomes. Nucl Acids Res 27:1767-1780

Boulding GE, deWaard RJ, Ang PK, Hebert DNP (2009) Population genetic structure of the salmon louse, Lepeophtheirus salmonis (Krøyer) on wild and farmed salmonids around the Pacific coast of Canada. Aquac Res 40:973-979

Boxaspen K (2006) A review of the biology and genetics of sea lice. ICES J Mar Sci 63:1304-1316

Boxshall AG, Bravo S (2000) On the identity of the common Caligus (Copepoda: Siphonostomatoida: Caligidae) from salmonid netpen systems in southern Chile. Contrib Zool 69:137-146

Bricknell IR, Bron JE, Bowden TJ (2006) Diseases of gadoid fish in cultivation: a review. ICES J Mar Sci 63:253-266

Burton RS, Byrne RJ, Rawson PD (2007) Three divergent mitochondrial genomes from California populations of the copepod Tigriopus californicus. Gene 403:53-59

Campell EM, Pert CC, Bowman AS (2009) RNA-interference methods for gene-knockdown in the sea louse, Lepeophtheirus salmonis: studies on a putative prostaglandin E synthase. Parasitology 136:867-874

Carvajal J, González L, George-Nascimento M (1998) Native sea lice (Copepoda: Caligidae) infestation of salmonids reared in netpen systems in southern Chile. Aquaculture 166:241-246

Costello JM (2009) The global economic cost of sea lice to the salmonid farming industry. J Fish Dis 32:115-118

Costello MJ (2006) Ecology of sea lice parasitic on farmed and wild fish. Trends Parasitol 22:475-483

Cunningham CW, Blackstone NW, Buss LW (1992) Evolution of king crabs from hermit crab ancestors. Nature 355:539-542

Dalvin S, Frost P, Biering E, Hamre L, Eichner C, Krossøy B, Nilsen F (2009) Functional characterisation of the maternal yolkassociated protein (LsYAP) utilising systemic RNA interference in the salmon louse (Lepeophtheirus salmonis) (Crustacea: Copepoda). Int J Parasitol 139:1407-1413

Dawson LHJ, Pike AW, Houlihan DF, McVicar AH (1997) Comparison of the susceptibility of sea trout (Salmo trutta L.) and Atlantic salmon (Salmo salar L.) to sea lice (Lepeophtheirus salmonis (Kroyer, 1837)) infections. ICES J Mar Sci 54:1129-1139

Dowton M, Austin AD (1999) Evolutionary dynamics of a mitochondrial rearrangement "hot spot" in the Hymenoptera. Mol Biol Evol 16:298-309

Fast MD, Ross NW, Mustafa A, Sims DE, Johnson SC, Conboy GA, Speare DJ, Johnson G, Burka JF (2002) Susceptibility of rainbow trout Oncorhynchus mykiss, Atlantic salmon Salmo salar and coho salmon Oncorhynchus kisutch to experimental infection with sea lice Lepeophtheirus salmonis. Dis Aquat Organ 521:57-68

Gee JM (1987) Impact of epibenthic predation on estuarine intertidal harpacticoid copepod populations. Mar Biol 96:497-510

González L, Carvajal J, George-Nascimento M (2000) Differential infectivity of Caligus flexispina (Copepoda, Caligidae) in three farmed salmonids in Chile. Aquaculture 183:13-23
González L, Carvajal J (2003) Life cycle of Caligus rogercresseyi (Copepoda: Caligidae) parasite of Chilean reared salmonids. Aquaculture 220:101-117

Hamre L, Glover K, Nilsen F (2009) Establishment and characterisation of salmon louse (Lepeophtheirus salmonis) laboratory strains. Parasitol Int 58:451-460

Hebert PD, Ratnasingham S, deWaard JR (2003) Barcoding animal life: cytochrome c oxidase subunit 1 divergences among closely related species. Proc Biol Sci 270:S96-S99

Heuch PA, Bjørn PA, Finstad B, Holst JC, Asplin L, Nilsen F (2005) A review of the 'Norwegian National Action Plan Against Salmon Lice on Salmonids': the effect on wild salmonids. Aquaculture 246:79-92

Huang X, Madan A (1999) CAP3: a DNA sequence assembly program. Genome Res 9:868-877

Humes AG (1994) How many copepods? Hydrobiologia 292-293:1-7

Johnson SC, Albright LJ (1992) Comparative susceptibility and histopathology of the response of naive Atlantic. Chinook and coho salmon to experimental infection with Lepeophtheirus salmonis Copepoda:Caligidae. Dis Aquat Organ 14:179-193

Johnson SC, Fast MD (2004) Interactions between sea lice and their hosts. Symp Soc Exp Biol 55:131-159

Johnson SC, Treasurer JW, Bravo S, Nagasawa K, Kabata Z (2004) A review of the impact of parasitic copepods on marine aquaculture. Zool Stud 432:229-243

Jones SR, Prosperi-Porta G, Kim E, Callow P, Hargreaves NB (2006) The occurrence of Lepeophtheirus salmonis and Caligus clemensi (Copepoda: Caligidae) on three-spine stickleback Gasterosteus aculeatus in coastal British Columbia. J Parasitol 92:473-480

Kabata Z (1979) Parasitic Copepoda of British fishes. The Ray Society, London

Ki JS, Park HG, Lee JS (2009) The complete mitochondrial genome of the cyclopoid copepod Paracyclopina nana: a highly divergent genome with novel gene order and atypical gene numbers. Gene 435:13-22

Kilpert F, Podsiadlowski L (2006) The complete mitochondrial genome of the common sea slater, Ligia oceanica (Crustacea, Isopoda) bears a novel gene order and unusual control region features. BMC Genomics 7:241

Kimura M (1980) A simple method for estimating evolutionary rate of base substitutions through comparative studies of nucleotide sequences. J Mol Evol 16:111-120

Koop BF, von Schalburg KR, Leong J, Walker N, Lieph R, Cooper GA, Robb A, Beetz-Sargent M, Holt RA, Moore R, Brahmbhatt S, Rosner J, Rexroad CIE, McGowan CR, Davidson WS (2008) A salmonid EST genomic study: genes, duplications, phylogeny and microarrays. BMC Genomics 9:545

Krkošek M, Ford JS, Morton A, Lele S, Myers RA, Lewis MA (2007a) Declining wild salmon populations in relation to parasites from farm salmon. Science 318:1772-1775

Krkošek M, Gottesfeld A, Proctor B, Rolston D, Carr-Harris C, Lewis MA (2007b) Effects of host migration, diversity and aquaculture on sea lice threats to Pacific salmon populations. Proc R Soc Lond B Biol Sci 274:3141-3149

Lavrov DV, Brown WM, Boore JL (2004) Phylogenetic position of the Pentastomida and (pan)crustacean relationships. Proc R Soc Lond B Biol Sci 271:537-544

Leong JS, Jantzen SG, von Schalburg KR, Cooper GA, Messmer AM, Liao NY, Munro S, Moore R, Holt RA, Jones SJM, Davidson WS, Koop BF (2010) Salmo salar and Esox lucius full-length cDNA clones reveal changes in evolutionary pressures on a posttetraploidization genome. BMC Genomics 11:279

Lowe TM, Eddy SR (1997) tRNAscan-SE: a program for improved detection of transfer RNA genes in genomic sequence. Nucl Acids Res 25:955-964

Macey JR, Larson A, Ananjeva NB, Fang Z, Papenfuss TJ (1997) Two novel gene orders and the role of light-strand replication in 
rearrangement of the vertebrate mitochondrial genome. Mol Biol Evol 14:91-104

Machida RJ, Miya MU, Nishida M, Nishida S (2002) Complete mitochondrial DNA sequence of Tigriopus japonicus (Crustacea: Copepoda). Mar Biotechnol 4:406-417

Machida RJ, Miya MU, Nishida M, Nishida S (2004) Large-scale gene rearrangements in the mitochondrial genomes of two calanoid copepods Eucalanus bungii and Neocalanus cristatus (Crustacea), with notes on new versatile primers for the srRNA and COI genes. Gene 332:71-78

Ohman MD, Hirche HJ (2001) Density-dependent mortality in an oceanic copepod population. Nature 412:638-641

Ohno S (1970) Evolution by gene duplication. Springer, New York

Øines Ø, Schram T (2008) Intra- or inter-specific difference in genotypes of Caligus elongatus Nordmann 1832? Acta Parasitol 53:93-105

Pike AW, Wadsworth SL (1999) Sealice on salmonids: their biology and control. Adv Parasitol 44:233-337

Piasecki W, MacKinnon BW (1995) Life cycle of a sea louse, Caligus elongatus von Nordmann, 1832 (Copepoda, Siphonostomatoida, Caligidae). Can J Zool 73:74-82

Schubart CD, Diesel R, Hedges SB (1998) Rapid evolution to terrestrial life in Jamaican crabs. Nature 393:363-365

Smith JL, Wootten R, Sommerville C (2007) The pathology of the early stages of the crustacean parasite, Lernaeocera branchialis (L.), on Atlantic cod, Gadus morhua L. J Fish Dis 30:1-11

Saksida S, Constantine J, Karreman GA, Donald A (2007) Evaluation of sea lice abundance levels on farmed Atlantic salmon (Salmo salar L.) located in the Broughton Archipelago of British Columbia from 2003 to 2005. Aquac Res 38:219-231

Sturmbauer C, Levinton JS, Christy J (1996) Molecular phylogeny analysis of fiddler crabs: test of the hypothesis of increasing behavioral complexity in evolution. Proc Natl Acad Sci USA 93:10855-10857

Tamura K, Dudley J, Nei M, Kumar S (2007) MEGA4: Molecular Evolutionary Genetics Analysis (MEGA) software version 4.0. Mol Biol Evol 24:1596-1599

Tjensvoll K, Glover KA, Nylund A (2006) Sequence variation in four mitochondrial genes of the salmon louse Lepeophtheirus salmonis. Dis Aquat Organ 68:251-259

Tjensvoll K, Hodneland K, Nilsen F, Nylund A (2005) Genetic characterization of the mitochondrial DNA from Lepeophtheirus salmonis (Crustacea; Copepoda). A new gene organization revealed. Gene 353:218-230

Todd CD, Walker AM, Ritchie MG, Graves JA, Walker AF (2004) Population genetic differentiation of sea lice (Lepeophtheirus salmonis) parasitic on Atlantic and Pacific salmonids: analyses of microsatellite DNA variation among wild and farmed hosts. Can J Fish Aquat Sci 61:1176-1190

Todd CD, Whyte BDM, MacLean JC, Walker AM (2006) Ectoparasitic sea lice (Lepeophtheirus salmonis and Caligus elongatus) infestations of wild, adult, one sea-winter Atlantic salmon Salmo salar returning to Scotland. Mar Ecol Prog Ser 328:183-193

Tully O, Nolan DT (2002) A review of the population biology and host-parasite interactions of the sea louse Lepeophtheirus salmonis (Copepoda: Caligidae). Parasitology 124:S165-S182

Walter TC, Boxshall GA (2008) World of Copepods database. Available online at http://www.marinespecies.org/copepoda: Consulted on 2010-01-06

Yazawa R, Yasuike M, Leong J, von Schalburg KR, Cooper GA, Beetz-Sargent M, Robb A, Davidson WS, Jones SRM, Koop BF (2008) EST and mitochondrial DNA sequences support a distinct Pacific form of salmon louse, Lepeophtheirus salmonis. Mar Biotechnol 10:741-749 